Article

\title{
Estimation of Evapotranspiration and Crop Coefficients of Tendone Vineyards Using Multi-Sensor Remote Sensing Data in a Mediterranean Environment
}

\section{Silvia Vanino ${ }^{1}$, Giuseppe Pulighe ${ }^{1, *}$, Pasquale Nino ${ }^{1}$, Carlo De Michele ${ }^{2}$, Salvatore Falanga Bolognesi ${ }^{2}$ and Guido D'Urso ${ }^{3}$}

1 Consiglio per la Ricerca in Agricoltura e l'Analisi dell'Economia Agraria, via Nomentana 41, 00161 Rome, Italy; E-Mails: vanino@inea.it (S.V.); nino@inea.it (P.N.)

2 ARIESPACE S.r.l. Spin Off Company Università degli Studi di Napoli Federico II, Centro Direzionale IS. A3, 80143 Naples, Italy; E-Mails: carlo.demichele@ariespace.com (C.D.M.); salvatore.falanga@ariespace.com (S.F.B.)

3 Department of Agricultural Sciences, University of Naples Federico II, Via Università 100, I-80055 Portici, Italy; E-Mail: durso@unina.it

* Author to whom correspondence should be addressed; E-Mail: giuseppe.pulighe@ tiscali.it; Tel.: +39-06-4785-6621; Fax: +39-06-4785-6299.

Academic Editors: Mutlu Ozdogan, Yoshio Inoue and Prasad S. Thenkabail

Received: 3 July 2015 / Accepted: 30 October 2015 / Published: 5 November 2015

\begin{abstract}
The sustainable management of water resources plays a key role in Mediterranean viticulture, characterized by scarcity and competition of available water. This study focuses on estimating the evapotranspiration and crop coefficients of table grapes vineyards trained on overhead "tendone" systems in the Apulia region (Italy). Maximum vineyard transpiration was estimated by adopting the "direct" methodology for ET proposed by the Food and Agriculture Organization in Irrigation and Drainage Paper No. 56, with crop parameters estimated from Landsat 8 and RapidEye satellite data in combination with ground-based meteorological data. The modeling results of two growing seasons (2013 and 2014) indicated that canopy growth, seasonal and 10-day sums evapotranspiration values were strictly related to thermal requirements and rainfall events. The estimated values of mean seasonal daily evapotranspiration ranged between 4.2 and $4.1 \mathrm{~mm} \cdot \mathrm{d}^{-1}$, while midseason estimated values of crop coefficients ranged from 0.88 to 0.93 in 2013, and 1.02 to 1.04 in 2014, respectively. The experimental evapotranspiration values calculated represent the maximum value in absence of stress, so the resulting crop coefficients should be used with some caution. It is concluded that the retrieval of crop parameters and
\end{abstract}


evapotranspiration derived from remotely-sensed data could be helpful for downscaling to the field the local weather conditions and agronomic practices and thus may be the basis for supporting grape growers and irrigation managers.

Keywords: evapotranspiration; crop coefficient; leaf area index; Landsat 8; RapidEye; remote sensing; vineyards; table grapes

\section{Introduction}

In semi-arid zones and in the Mediterranean environment, water scarcity and droughts are an increasingly frequent and widespread phenomenon, and a major limitation for viticulture productivity. In particular, in semi-arid regions of southern Europe, table grapes (Vitis vinifera L.) represent a key economic activity [1], where productivity, defined as the ratio between crop produced and water consumed [2,3], is directly associated with the vineyard water consumption and evapotranspiration [4]. In this context, the accurate monitoring of irrigation water management, such as regulated deficit irrigation and partial root-zone drying irrigation, has emerged as a potential way to increase water-use efficiency while maintaining yields of high quality [5-9], with profitable economic benefits for the grape growers linking water and grape prices and quality of grapes [10]. Timely and accurate estimation of table grapes' water requirements are paramount for adequate irrigation scheduling and irrigation planning, to regulate the appropriate balance between vegetative growth, yield, and berry composition, and to save water. Furthermore, in dry areas the enhanced pressure on water resources with other uses requires an improvement of environmental sustainability of grapevine production according to future climate change scenarios [11].

In the past two decades, a large and growing strand of the literature has investigated various methods to calculate vineyard water requirements. Several studies were based either on measurements from weighing lysimeters $[6,12,13]$, or on surface energy balance such as the Eddy Covariance and Bowen ratio methods [14-18]. Overall, these studies indicate significant variation on water requirements and more generally do not provide spatial trends of evapotranspiration, since the measured values are mostly restricted and influenced by a small footprint area [19].

The FAO-56 model is the most commonly used method for the estimation of crop water requirements $[20,21]$. Crop potential evapotranspiration $\left(\mathrm{ET}_{\mathrm{p}}\right)$ is estimated as the product of the reference evapotranspiration $\left(\mathrm{ET}_{0}\right)$ and the crop coefficient $\left(\mathrm{K}_{\mathrm{c}}\right)$. The $\mathrm{ET}_{0}$ value is estimated by meteorological data and represents the effects of weather conditions on the evapotranspiration process [22]. The $\mathrm{K}_{\mathrm{c}}$ coefficient is specific to each crop and to the method used for $\mathrm{ET}_{0}$ [23], and reflects the canopy development and water management practices over the course of the growing season. Consequently, specific values of $\mathrm{K}_{\mathrm{c}}$ are necessary to fit different climate regions and soil type conditions, especially considering future climate change scenarios that predict alterations in the growing season period and phenological stages [24,25]. 
In recent years, several attempts have been made to implement remote sensing data with the FAO-56 model, in order to provide a reliable alternative to the indirect estimation of $\mathrm{ET}_{\mathrm{p}}$ and crop coefficient over large scales $[4,23,26,27]$, allowing accurate monitoring of irrigation water management. Remote sensing approaches in the visible and near infrared ranges can be used to determine the crop water requirements in absence of stress, such as occurs for table grapes [28]. In addition, they do not require the development of complex physical models that work with detailed input datasets. In this case, the interpretation of remotely sensed data is based on the known relationships between spectral reflectance and biophysical crop parameters.

A variety of approaches, both empirical and physically-based methodologies, are used for ET $\mathrm{p}$ and $\mathrm{K}_{\mathrm{c}}$ estimations. The first type of methods commonly uses the empirical relationships between Vegetation Indices (VI) and field observations to estimate the energy partitioning and canopy parameters like $\mathrm{K}_{\mathrm{c}}$, while the second type of methods relies on the application of radiative transfer models and strong theoretical and physical relationships that reflect the plant water status, crop characteristics, and soil water management [4,29]. A comprehensive review of remotely-sensed Vegetation Indices used to estimate canopy parameters and their advantages and disadvantages was proposed by Glenn et al. and Allen et al. [30,31]. Although physically-based methods outperform those based on a VI approach, the latter methods are simple to deploy and maintain both in time and space [28]. VI widely used to estimate $\mathrm{K}_{\mathrm{c}}$ are the Normalized Difference Vegetation Index (NDVI), the Soil Adjusted Vegetation Index (SAVI), and the Weighted Difference Vegetation Index (WDVI). A considerable amount of research has been conducted in recent years to estimate $\mathrm{K}_{\mathrm{c}}$ and the temporal evolution for annual and orchard crops under different climate conditions [2,4,26,27,32-35].

However, very few studies evaluate the crop coefficients of overhead trellis system vineyards, also known in Italian as "tendone" (meaning "big tent") [36], probably due to the fact that it is typical of only some regions in Southern Italy and Southern America. In table grapes, standard $\mathrm{K}_{\mathrm{c}}$ values are obtained from the literature in vines trained on a trellis system developed under different climatic conditions. Nevertheless, crop coefficients primarily depend on the dynamics of canopies, light absorption by the canopy, and canopy roughness, which affects turbulence, crop physiology, leaf age, and surface wetness [37]. Moreover, factors determining the $\mathrm{K}_{\mathrm{c}}$ of vineyards include the canopy height and architecture of the trellis system, the fraction of the soil covered by the crop, and the presence of mulch [38]. Thus, it is always recommended to adapt the $\mathrm{K}_{\mathrm{c}}$ to the local climate, cultivars, and management practices, especially in orchards and vineyards, where the standard parameters may vary considerably from one area to another [26].

Although extensive research has been carried out on the retrieval of crop biophysical variables, there are few studies that have investigated the estimation of $\mathrm{K}_{\mathrm{c}}$ from satellite data for vineyards in the Mediterranean. The main objective of this work is to determine evapotranspiration and $\mathrm{K}_{\mathrm{c}}$ linked to the Growing Degree Days (GDD) and the main phenological stages of a "tendone" vineyard in the South Italy. The research was carried out during two growing seasons using satellite reflectance data and the FAO-56 single crop coefficient approach to establish a relationship between VI and $\mathrm{K}_{\mathrm{c}}$. The approach described in this paper also constitutes the basis of the irrigation advisory services using Earth Observation (E.O.) data, such as the "IRRISAT" service operational in Italy [39]. 


\section{Material and Methods}

\subsection{Study Area and Vineyard Description}

The study area is located in the Apulia region (Figure 1) in the southeastern part of the Italian peninsula, where over $70 \%$ of the total area is occupied by agriculture and vineyards cover about $26 \%$ of the crop area [40]. The regional topography is mainly flat or slightly sloping, with the exception of the Gargano area, situated in the northwest of the region. The climate of the study area is classified as Mediterranean semi-arid, characterized by moderately cold and rainy winters and dry summer seasons. Mean annual precipitation is about $550 \mathrm{~mm}$, concentrated in the fall and winter; long-term mean air temperature is $15.4{ }^{\circ} \mathrm{C}$, while the minimum and maximum yearly temperatures are 3.5 and $29.5{ }^{\circ} \mathrm{C}$, respectively. The climate, rainfall in particular, exhibits a marked inter-annual variability that makes water availability a permanent threat to the economic development and ecosystem conservation of the region [41]. The soil is typical of the Capitanata region, with a well-differentiated profile, characterized by Quaternary marine sediments of illitic/smectitic composition that originate clay soils with vertic features (cambisols, entisols, vertisols) [42]. Due to its geo-climatic conditions, the region suffers from overall water exploitation, which exposes the water supply system to severe water scarcity events.

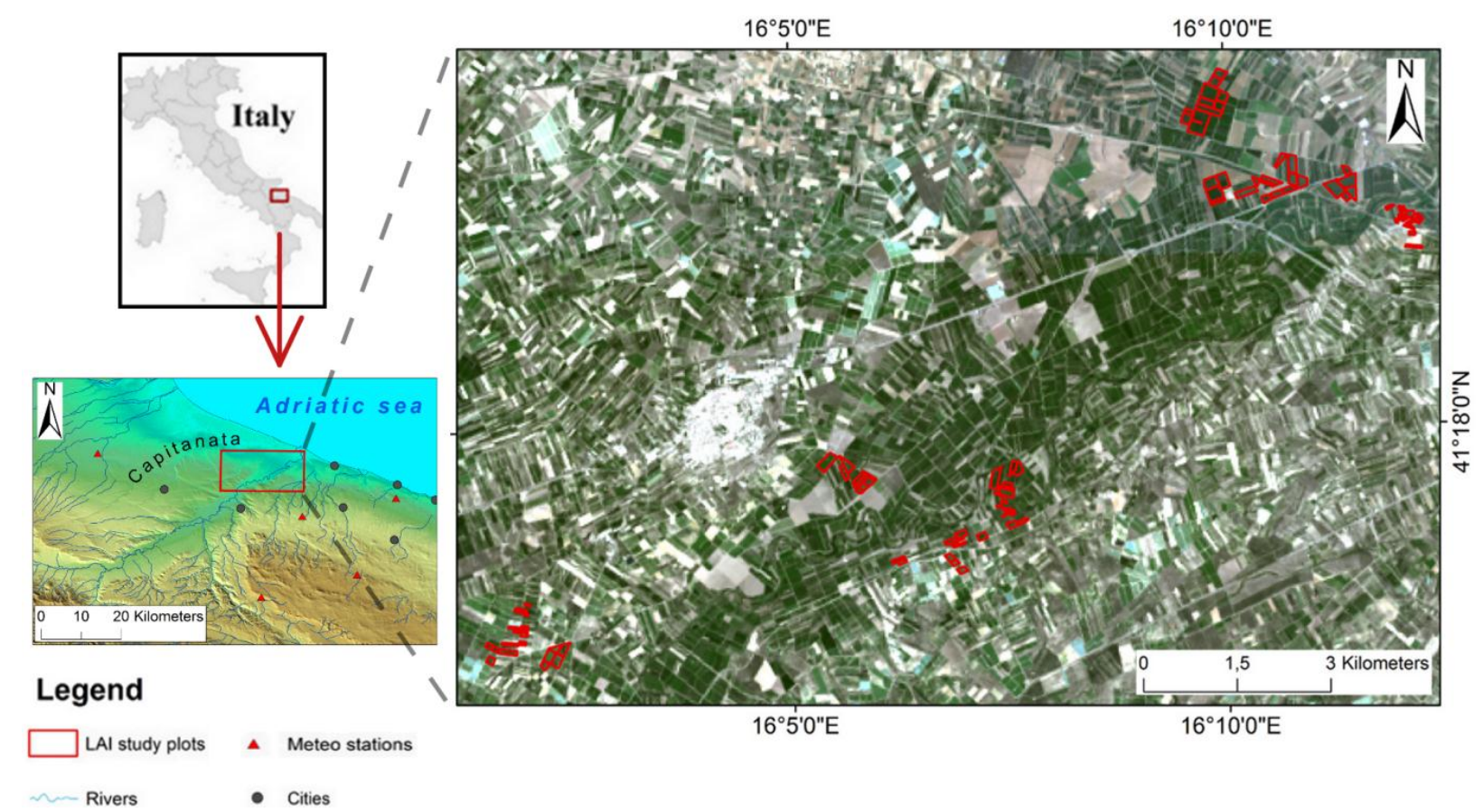

Figure 1. Study area location with overview of LAI plot measurements. Natural color composition of Landsat 8 image acquired on 26 August 2014.

The investigations have been carried within the Land Reclamation and Irrigation Consortium Capitanata, one of the largest agricultural irrigation districts of Southern Italy (Figure 1). This region mainly contains vineyards and orchards over flat terrain. In particular, field data have been collected in a 13 ha multiplot vineyard $\left(41^{\circ} 17^{\prime} 29^{\prime \prime}\right.$ North latitude, $16^{\circ} 07^{\prime} 22^{\prime \prime}$ West longitude) trained on a "tendone" system, with commercial table grapes (cultivars Italia, Victoria, and RedGlobe), uncovered and drip irrigated (Figure 2). The row and vine spacing in the vineyard was generally $2.3 \times 2.3 \mathrm{~m}$, about $2 \mathrm{~m}$ high 
with a plant density of 1890 plants $\cdot \mathrm{ha}^{-1}$. Agronomic management generally maintains the vegetation under non-water stress conditions and soil surface free of weeds and cover crop.

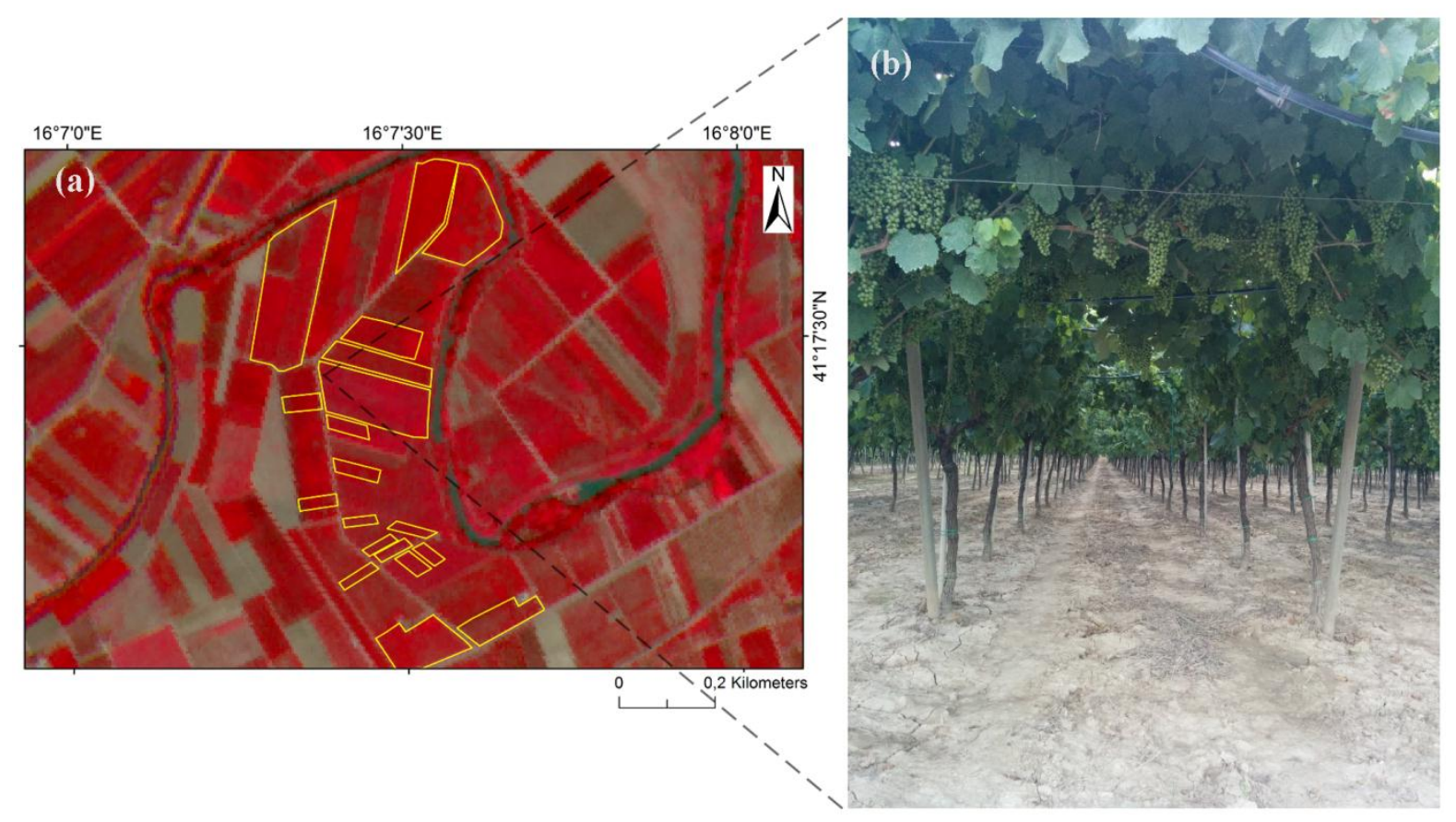

Figure 2. (a) Overall view of the vineyard study field displayed on a RapidEye image acquired on 2 August 2014 (infrared false color composition 532). Yellow borders show the experimental plots. (b) Canopy growth of the vineyard inter-row acquired on 24 July 2014.

\subsection{Dataset}

The dataset includes Landsat 8 and RapidEye optical images (in the visible and near infrared ranges), agrometeorological data, and in situ Leaf Area Index (LAI) measurements.

\subsubsection{Satellite Images}

Earth Observation images used to estimate crop coefficients were collected from the sensor OLI (Operational Land Imager), onboard the Landsat 8 Mission (formerly the Landsat Data Continuity Mission, LDCM). The data are available for download free of charge from the U.S. Geological Survey-USGS Earth Explorer data repository.

In addition, several RapidEye high-resolution images at $6.5 \mathrm{~m}$ Ground Sample Distance at nadir (generally resampled to 5-m pixel size), were also acquired. The study field concerns two frames of Landsat 8 images (Path 188, Row 31), radiometrically calibrated and orthorectified using ground control points, and a set of high-resolution RapidEye images, radiometrically calibrated. Table 1 summarizes the cloud-free satellite data used and processed over the study area. The temporal frequency of the entire data set acquired allows us to monitor the vegetation development throughout the growing seasons. 
Table 1. Overview of the imagery dataset used in the study area.

\begin{tabular}{|c|c|c|c|c|c|}
\hline Satellite Data & GSD* (m) & Processing Level & Revisit Time & N. of Images & Acquisition Dates \\
\hline Landsat 8 OLI & 30 & $1 \mathrm{~T}$ & 16 day & 14 & $\begin{array}{c}\text { from } 19 / 05 / 2013 \text { to } \\
26 / 08 / 2014\end{array}$ \\
\hline RapidEye MSI & 6.5 & 1B & 1 day & 10 & $\begin{array}{c}\text { from } 10 / 06 / 2014 \text { to } \\
29 / 09 / 2014\end{array}$ \\
\hline
\end{tabular}

Note: *Ground sample distance.

\subsubsection{Agrometeorological Data and Field Data}

Agrometeorological data were acquired from five stations managed by Assocodipuglia, the agrometeorological service of the Apulia Region. Daily data of precipitation, evapotranspiration, atmospheric pressure, global radiation, air temperature, humidity, and wind speed were acquired for both years. Daily air temperature was used to calculate the GDD index from 1 April to 31 October, computed as the difference between the daily mean temperature and the base temperature $\left(10{ }^{\circ} \mathrm{C}\right)$ [43]. In addition, other ancillary and administrative data were used to improve elaborations.

\subsubsection{In Situ LAI}

In situ LAI measurements $\left(\mathrm{m}^{2} \cdot \mathrm{m}^{-2}\right)$ were collected on 23 and 24 July 2014 for 38 sample plots. Field non-destructive measurements of LAI and leaf mean tilt angle were made with LICOR LAI-2000 Plant Canopy Analyzer [44], which works by comparing the intensity of diffuse incident illumination measured at the bottom of the canopy with that arriving at the top. In order to reduce the effect of multiple scattering on LAI-2000 measurements, the instrument was only operated near dusk and dawn (6:30-9:30 am; 6:30-8:30 pm) under diffuse radiation condition, using one sensor for both above and below stand measurements. In order to prevent interference caused by the operator's presence and the illumination condition, the sensor field of view was limited with a $180^{\circ}$ view-cap. Measurements were azimuthally oriented opposite to the sun azimuth angle. LAI measurements were taken with the instrument held a few centimeters above the soil, generally within three days of image data acquisition.

A measurement of ambient light was made with the sensor extended upward and over the top of the canopy at arm's length. Eight below-canopy readings were then made. This pattern has been repeated three times per spot, and the resulting 24 samples comprise one full set of measurements. Finally, each center of the LAI-2000 transects was geolocated by using GPS (Global Position System) measurements. This measurement protocol allowed us to determine statistically meaningful LAI values, characterized by a low ratio between the standard error of the LAI (SEL) and LAI (SEL/LAI ranged between $\approx 0.03$ and $\approx 0.07$ ); thus, the actual LAI should be within $10 \%$ of the LAI sample mean (Figure 3 ).

\subsection{Methods}

The application of the procedure is achieved by the integration of EO techniques and meteorological data of the study area. The conceptualization has been developed by D'Urso [45] and implemented into the SIMODIS model (SImulation and Management of On-Demand Irrigation System). The estimation of crop evapotranspiration under standard conditions $\left(\mathrm{ET}_{\mathrm{p}}-\mathrm{mm} / \mathrm{d}\right)$-disease-free, adequate fertilization, and soil water availability - has been carried out using the FAO's Penman-Monteith 
method, which requires standard meteorological data such as solar radiation $(\mathrm{S})$, air temperature $\left(\mathrm{T}_{\mathrm{a}}\right)$, air humidity (RH), wind speed (U), and biophysical parameters that are crop-specific, such as albedo $(r)$, LAI, and crop height $\left(h_{c}\right)$ [20]. The value of $\mathrm{ET}_{\mathrm{p}}$ is a function of the crop parameters and meteorological data, and the procedure, known as the one-step approach, is computed as:

$$
E T_{p}=f\{r, L A I, h c \mid T a, R H, S, U\}
$$

Since crop parameters (mainly $r$ and LAI) are very difficult to obtain in the open field without specific instruments, $\mathrm{ET}_{\mathrm{p}}$ is calculated in the routine irrigation management by multiplying $\mathrm{ET}_{0}$ by $\mathrm{K}_{\mathrm{c}}$, starting from an $\mathrm{ET}_{0}$ assuming an ideal crop with standard parameters $\left(h_{c}=0.12 \mathrm{~m}, r=0.23, \mathrm{LAI}=2.88\right)$ and a $\mathrm{K}_{\mathrm{c}}$ extracted from the FAO-56 table, following a single $\mathrm{K}_{\mathrm{c}}$ approach [20].

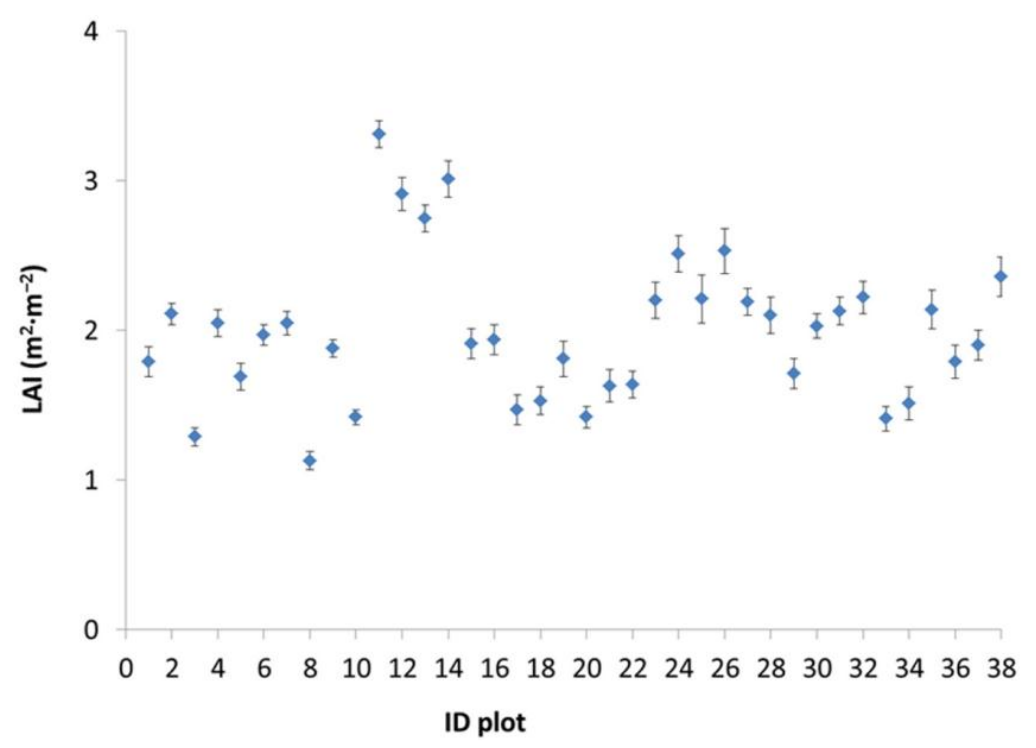

Figure 3. Field estimates of LAI collected on 23-24 July 2014 with a LICOR LAI-2000 Plant Canopy Analyzer. The filled circles show the average LAI with the standard error.

It should be noted that $\mathrm{ET}_{\mathrm{p}}$ calculated in this way represents the maximum value, (i.e., minimum canopy resistance), so the resulting $\mathrm{K}_{\mathrm{c}}$ values, if compared with values reported in the literature, should be used with caution. The comparison between the results of the proposed methodology and field measurements-including fluxes of latent heat by means of micrometeorological instrumentations - requires fully controlled conditions (especially for irrigation), which were not available at the current study site. However, we assume that the model can be applied to the studied canopy, having been validated in the course of field experiments on different fully irrigated crops [29,39]. Actual evapotranspiration from a well-watered crop will generally approach $\mathrm{ET}_{\mathrm{p}}$ during the active growing stage, but it falls below it toward the end of the growing season as the plants begin to dry out. Diversely from our ET 0 estimates, actual evapotranspiration depends on the conditions of soil water availability, and is only possible to compute through complex measurements in the open field or by filling out a detailed hydrological balance, taking into account all the parameters for the simulation of water transport/flow in the Soil, Plant Atmosphere system, using numerical schematization. In this case, the value of $\mathrm{ET}_{\mathrm{p}}$ determined with the approach proposed here is used as an upper limiting condition [46]. This kind of analysis has been carried out for some perennial tree crops in Sicily [47], where soil water and surface energy balances with visible, near, and thermal infrared data 
have been carried out. These previous studies support the assumption of validity, provided that the canopy parameters, i.e., LAI, are adequately described. Finally, crop water requirements can be accounted for in a simple way by subtracting the net precipitation $\left(P_{n}\right)$ from $\mathrm{ET}_{\mathrm{p}}$.

In order to describe the amount of intercepted water from the plant surface, $P_{n}$ is calculated as a function of the actual precipitation $(P), \mathrm{LAI}$, and fractional cover. The semi-empirical model of interception [48] is described by the following relationship:

$$
P_{n}=P-a L A I\left(1-\frac{1}{1+\frac{f \operatorname{cover} \cdot P}{a L A I}}\right)
$$

where $P\left(\mathrm{~cm} \cdot \mathrm{d}^{-1}\right)$ and $a\left(\mathrm{~cm} \cdot \mathrm{d}^{-1}\right)$ are empirical parameters representing the crop saturation per unit foliage area ( $\sim 0.28$ for most crops), and fcover is the fractional vegetation cover derived from LAI using a polynomial empirical expression where coefficients are determined from field measurements and are valid for a wide range of crops $\left(\mathrm{LAI} \leq 5 \mathrm{~m}^{2} \cdot \mathrm{m}^{-2}\right)$.

$\mathrm{K}_{\mathrm{c}}$ values are extremely variable, even within the same type of crop, depending on many factors, i.e., date and seeding density, intake of nutrients, nature of the soil, and agronomic practices. $\mathrm{K}_{\mathrm{c}}$ is basically the ratio of the $\mathrm{ET}_{\mathrm{p}}$ to the $\mathrm{ET}_{0}$, and can be computed as follows $[45,49]$ :

$$
K_{c}=\frac{E T_{p}\left(r^{*}, L A I^{*}, h c^{*}, T a, R H, U, K^{\downarrow}\right)}{E T_{0}\left(r, L A I, h c, T a, R H, U, K^{\downarrow}\right)}
$$

where $r^{*}, \mathrm{LAI}^{*}$ and $h_{c}{ }^{*}$ represent the parameters of the crop vegetation present at the time of the satellite overpass, which can be related to satellite observations, while $K^{\downarrow}$ represent the global incoming short-wave radiation flux density. The value of $\mathrm{K}_{\mathrm{c}}$ depends both on the crop parameters (except albedo, which is also influenced by the degree of humidity of the soil), which can be considered relatively stable for a period of 1-2 weeks, and the weather conditions of the study area, which instead vary in time. A sensitivity analysis of the value of $K_{c}$ with respect to these parameters showed that the value of $\mathrm{K}_{\mathrm{c}}$ is more closely related to vegetation parameters $r^{*}$ and $\mathrm{LAI}^{*}$, and that the sensitivity of the change in the crop height is higher in autumn than in summer [45]. This is due to the fact that, at the daily scale, the aerodynamic component of evapotranspiration is of much less importance than the radiative. A flow-chart of the processing chain of this procedure can be found in Vuolo et al. [39]. The validation has been carried out over different crops (including vineyards), thereby fulfilling the "standard conditions" for $\mathrm{ET}_{\mathrm{p}}$ by means of eddy-covariance independent measurements [29,39]. Since LAI represents the main parameter, it can be taken as the reference variable for the calibration of this method to local conditions, as described later.

Recent studies conducted in semi-arid areas confirm this trend [50]; in fact, a percentage change of $50 \%$ in $h_{c}{ }^{*}$ corresponds to a variation of $5 \%$ of $\mathrm{K}_{\mathrm{c}}$. Therefore, a constant value of $h_{c}=0.4 \mathrm{~m}$ has been set in this study, valid for the climatic conditions of the Mediterranean area, reducing the calculation to the estimation of $r$ and LAI. 


\section{Data Processing for Deriving EO-Based Crop Development Maps}

A total of 14 Landsat 8 images and 10 RapidEye images were used for both growing seasons. The pre-processing phase of satellite images was achieved in two steps. Firstly, Landsat 8 scenes were orthorectified by using additional Ground Control Points and a Digital Elevation Model, while RapidEye scenes were orthorectified using only the image's rational functions. Secondly, the images have been atmospherically corrected using the ATCOR-2 software suite in ERDAS imagine, which incorporates the MODerate resolution atmospheric TRANsmission (MODTRAN version 4) model and uses look-up tables with pre-calculated model simulations for different satellite sensor types and a range of atmospheric conditions [51,52]. Furthermore, supervised classification of Landsat 8 images was performed to identify at each acquisition the plots of agricultural land cover with vegetation and areas with bare soil and/or urban areas.

In order to implement the FAO-56 model, for each satellite image a set of maps of $\mathrm{K}_{\mathrm{c}}$ were derived on the basis of LAI and $r$ maps. The surface albedo, needed to derive the net radiant flux, is an approximation of the hemispherical and spectrally integrated surface albedo, and was extracted as part of the value-added products available in ATCOR-2 after the atmospheric correction [53]. LAI is a biophysical surface parameter defined as the total one-sided area of photosynthetic tissue per unit of ground area [54]. The estimate of the LAI was performed based on the simplified Clevers' Leaf Area Index by Reflectance model, CLAIR [55], based on the Weighted Difference Vegetation Index (WDVI). The WDVI is a radiometric index calculated, for each pixel of the image, from the values of reflectance $\mathrm{r}_{\text {SRED }}$ and $\mathrm{r}_{\mathrm{sNIR}}$, respectively, in the bands of red $(0.63-0.69 \mu \mathrm{m})$ and the near infrared $(0.76-0.90 \mu \mathrm{m})$. The ratio of near-infrared and red soil reflectance is also known in the literature as the "soil line slope," usually between 0.9 and 1.3. The effect of weighting the red band with the slope of the soil line is the maximization of the vegetation signal in the near-infrared band and the minimization of the effect of soil brightness. The LAI is related with WDVI of the observed vegetation, through the following expression, deduced from a simplified analysis of the radiative behavior of different types of crops $[50,55,56]$ :

$$
L A I=-\frac{1}{\alpha^{*}} \ln \left(1-\frac{W D V I}{W D V I_{\infty}}\right)
$$

where $\alpha^{*}$ is an extinction coefficient (increase of WDVI for an unitary increase of LAI-an empirical shape parameter, mainly depending on canopy architecture and computed from field measurement and considered to be 0.39 in this study, corresponding to the minimum error between the observed and estimated LAI), and WDVI $\infty$ is the asymptotical value of WDVI for LAI $\rightarrow \infty$, and is calculated at each acquisition at the target "vegetation cover (not woody) very dense and uniform" or maximum vegetation (agricultural) cover (usually between 0.55 and 0.75 ).

In situ LAI measurements have been used to produce LAI maps from Landsat 8 and RapidEye images by applying the semi-empirical CLAIR model based on an inverse relationship between the WDVI and LAI [55,57].

The CLAIR model needs to be calibrated by estimating the extinction coefficient $\alpha^{*}$. Equation (4) must be inverted, fixing the LAI, WDVI, and WDVI $\infty$ values. WDVI $\infty$ was calculated $\left(\mathrm{r}_{\mathrm{sNIR}} / \mathrm{r}_{\mathrm{sRED}}=1.35\right.$, WDVI $\infty=0.55$ ) so as to create a correspondence of pixels with maximum vegetation cover. The resulted $\alpha^{*}$ values were in the range of $0.34-0.70$. The final value of $\alpha^{*}=0.39$ corresponds to the minimum error between observed and estimated LAI, leading to an average error of $25 \%$ in the estimation of the LAI. 
To test the model prediction accuracies, we used the root-mean-square error (RMSE) and the coefficient of determination $\left(\mathrm{R}^{2}\right)$ between measured and predicted LAI. According to the FAO-56 model, the ET0 computed from the agrometeorological variables using the Penman-Monteith equation is used to calculate the value of $\mathrm{K}_{\mathrm{c}}$ (according to the analytical method), where $\mathrm{K}_{\mathrm{c}}$ is the ratio between $\mathrm{ET}_{\mathrm{p}}$ and $\mathrm{ET}_{0}[20] . \mathrm{K}_{\mathrm{c}}$ incorporates and synthesizes all the effects on the evapotranspiration related to morpho-physiological characteristics of the different crops - phenological stage, degree of soil cover, soil and climate conditions - that make them different from the reference crop.

The mean value of the ratio between $\mathrm{ET}_{\mathrm{p}}$ and $\mathrm{ET}_{0}$ over a period of about seven days around the date of satellite's passage is applied twice, once with standard values of LAI, $r$, and crop height for a reference surface, and once by using the LAI, $r$, and crop height (this latter is fixed for tree crops) from satellite images. To speed up this processing in a GIS environment, we derive a polynomial expression of degree 4, whose coefficients are derived by calculating the $\mathrm{K}_{\mathrm{c}}$ intervals of LAI and albedo targets (i.e., LAI in range $0-5$ and step 0.2 ; albedo in range 0.05 to 0.5 and step 0.01 ). The coefficients mostly depend on meteorological data, and they are dimensionless as LAI and $\mathrm{K}_{\mathrm{c}}$. This procedure is not strictly needed, since we could directly use the FAO-56 method on a daily basis, but it has the advantage of showing the direct link between $\mathrm{K}_{c}$, LAI, and albedo. Once we derive albedo and LAI from the satellite images and calculate the coefficients for a given time interval, in a GIS environment we derive the $K_{c}$ map on a pixel-by-pixel basis. One important advantage of deriving canopy parameters or crop coefficients from spectral measurements is that their values do not depend on other variables such as planting date and density, but on the effective cover.

\section{Results and Discussion}

\subsection{Weather Conditions, Reference ET, and Phenology}

Rainfall and temperature in 2013 and 2014 were slightly different but in accordance with climatological averages for the study area (Figure 4). The year 2013 has been characterized by a rainy winter and spring and a dry summer, with anomalously high precipitation in August and in the autumn, while 2014 experienced a rainy spring: long-term average precipitation from April to June was $210 \mathrm{~mm}$, about 35\% of the annual amount. This situation affected the crop water requirements during the growing season. Annual rainfall and mean temperature were $629.2 \mathrm{~mm}$ and $16.2{ }^{\circ} \mathrm{C}$ for 2013 , and $607.4 \mathrm{~mm}$ and $16.7^{\circ} \mathrm{C}$ for 2014, respectively. Total rainfall from 1 June to 30 September was $114.4 \mathrm{~mm}$ (18\% of the annual amount) in 2013 and $103 \mathrm{~mm}$ (27\% of the annual amount) in 2014, respectively.

Seasonal variations of $\mathrm{ET}_{0}$ are shown in Figure 5 for 2013 and 2014, respectively. The total amounts of ETo in the growing season (1 June to 30 September) were similar in both years: $511 \mathrm{~mm}$ in 2013 and $501.6 \mathrm{~mm}$ in 2014. The average daily ETo was $4.2 \mathrm{mmd}^{-1}$ and $4.1 \mathrm{mmd}^{-1}$ in the first and second year, respectively. In the 2013 growing season the lowest daily $\mathrm{ET}_{0}$ was $1.3 \mathrm{mmd}^{-1}$ (30 September) and the highest was $6.7 \mathrm{mmd}^{-1}$ (24 June). In the 2014growing season, ETo values ranged from $1.7 \mathrm{mmd}^{-1}$ (1 September) to $6.7 \mathrm{mmd}^{-1}$ (29 June). The transpiration values reported in this study are consistent with those reported by Suvocărev et al. [22] (4.3-4.4 $\left.\mathrm{mmd}^{-1}\right)$ and Teixeira et al. [2] (3.9-4.4 $\left.\mathrm{mmd}^{-1}\right)$ for table grapes trained on an overhead trellis system, although they cannot be directly compared because they were measured at the ground. 

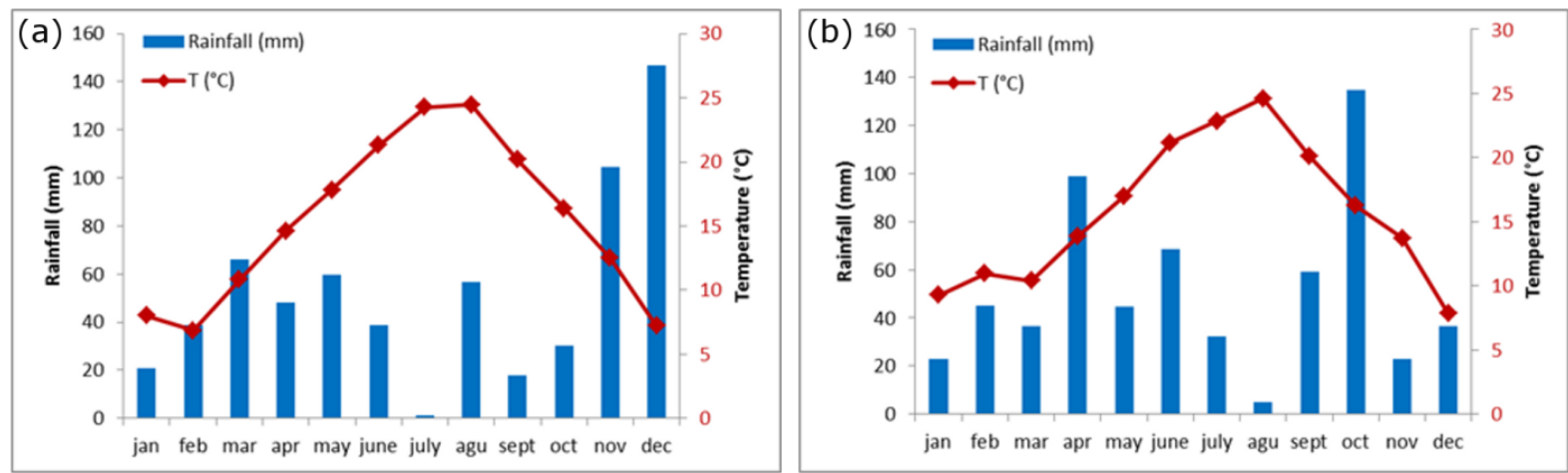

Figure 4. Seasonal trends of temperature and rainfall at an agrometeorological station in Andria for the years 2013 (a) and 2014 (b).
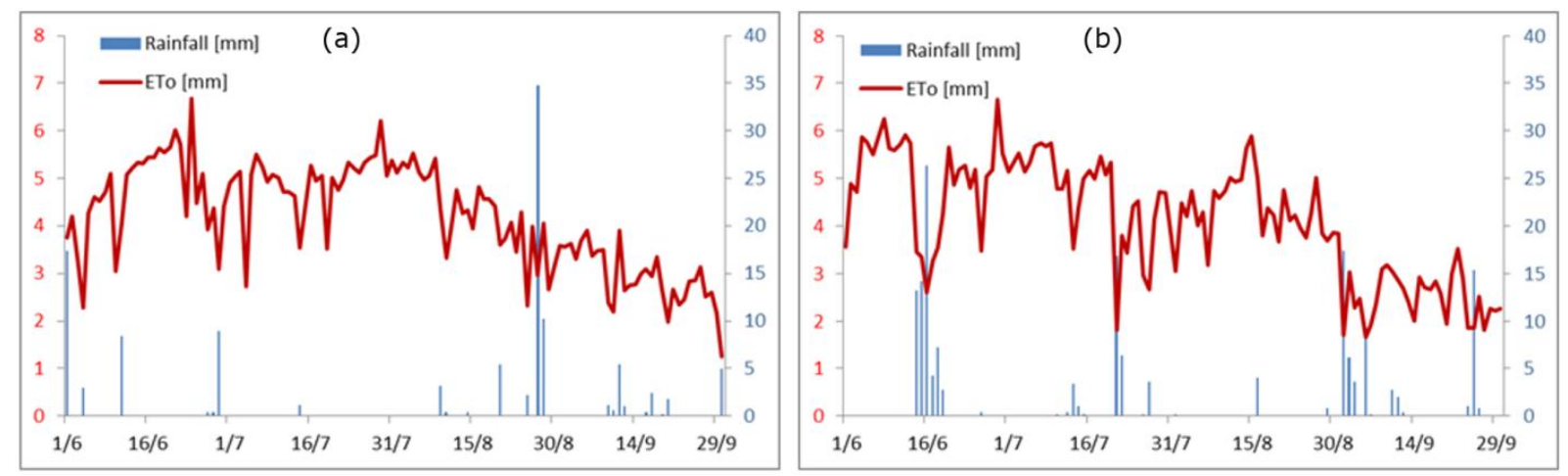

Figure 5. Seasonal trends of ETo and rainfall events during the growing season for the years 2013 (a) and 2014 (b).

In addition, the GDD index was calculated using the data from a weather station located near the sample plots. The length of four key phenological stages was also identified based on mean dates registered in the study area. The GDD index from 1 April to 31 October is similar for both seasons and ranged from 2108 GDD in 2013 to 2128 GDD in 2014 (Table 2), thus the study area was classified as Region IV (hot) [58]. Nevertheless, the GDD accumulation up to flowering in the 2014 growing season was markedly lower than in 2013.

Table 2. Phenological stages and cumulative GDD during the 2013 and 2014 growing seasons.

\begin{tabular}{cccc}
\hline Phenology $*$ & Time & GDD 2013 & GDD 2014 \\
\hline Bud break & 1-6 April & 0 & 0 \\
Flowering & 20-30 May & 341 & 279 \\
Veraison & 16-24 July & 981 & 1040 \\
Harvest & 10-15 Sept. & 1747 & 1766 \\
- & 31 October & 2018 & 2128 \\
\hline
\end{tabular}

Note: * Observed mean dates of key phenological stages were obtained from the research unit Consiglio per la Ricerca in Agricoltura e l'Analisi dell'Economia Agraria UTV, Turi (Tarricone L., personal communication).

The accumulation of degree-days has important implications for the length of the growth stages and water availability [59]. In fact, it has been demonstrated that canopy development is highly correlated with GDD [12,60] and consequently the canopy cover and shaded area control the seasonal values of 
the $K_{c}$ [12]. Overall, these studies suggested that the observed $K_{c}$ values should be linked to the cumulative GDD of specific agro-climatic locations in order to minimize the effects of year-to-year weather variations. Clearly, the seasonal development and length of growing stages on other study areas can be very different compared with those considered by the FAO-56 paper.

Up to now, a number of studies pointed out that changes in climate led to significant impacts on the phenology time series, for example shifts in phenological timing of bud-burst to harvest $[25,61,62]$. These results further support the need for setting $K_{c}$ values for the new climate change projections, as well as agronomic practices aimed at the enhancement of soil water availability (i.e., mulching, netting, and biochar) $[11,22,63]$.

\subsection{Temporal Evolution of LAI and Kc}

Consequently, the measurements made in the field were compared with the data elaborated from high-resolution satellite images (RapidEye). The data are an average of the pixels belonging to the same polygon of land cover. The scatterplot between field LAI measured and satellite LAI estimates are shown in Figure 6. The RMSE and $\mathrm{R}^{2}$ between measured and predicted LAI are 0.33 and 0.71 , respectively.

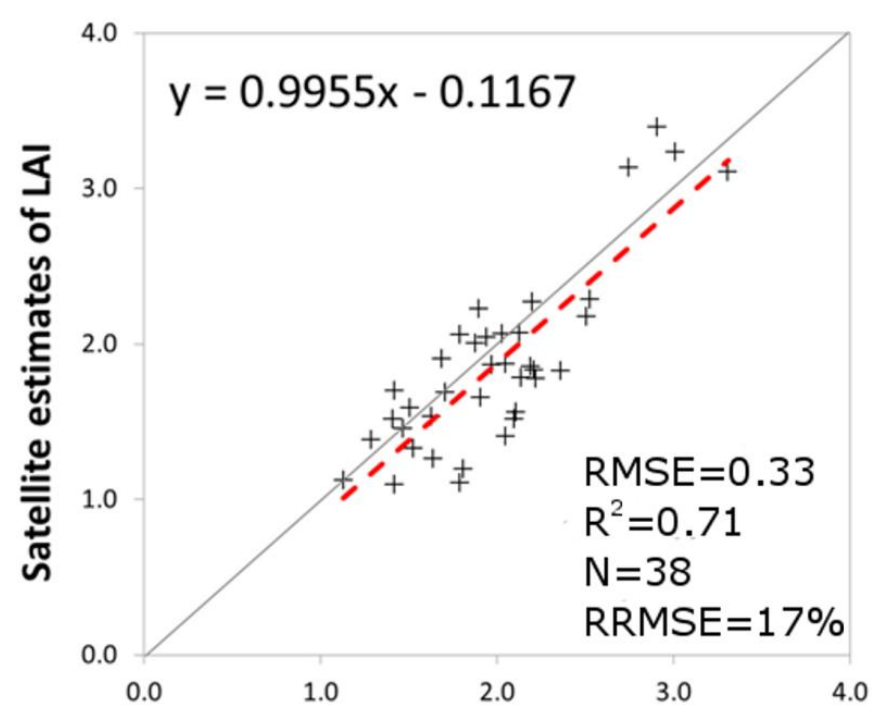

Field estimates of LAI

Figure 6. Scatter plots $(n=38)$ of field LAI estimates (23 to 24 July 2014) and satellite estimates of LAI (RapidEye image, 2 August 2014). RMSE: root mean square error. $\mathrm{R}^{2}=$ coefficient of determination. RRMSE: relative root mean square error. The broken red line shows the ordinary least squares linear regression fits. In black is the 1-to-1 line.

Seasonal $\mathrm{K}_{\mathrm{c}}$ values were obtained by dividing $\mathrm{ET}_{\mathrm{p}}$ with the reference evapotranspiration calculated as previously described. The time evolution of measured $K_{c}$ for the growing seasons 2013 and 2014 are reported in Tables 3 and 4, respectively. During the 2013 growing season the $\mathrm{K}_{\mathrm{c}}$ value moves from a minimum of 0.43 to a maximum of 1.23 on the date of harvest, while in 2014 the $\mathrm{K}_{\mathrm{c}}$ moves from a minimum of 0.14 to a maximum of 1.42 . The $\mathrm{K}_{\mathrm{c}}$ mean values were higher in May and June in 2013, and from July to the beginning of September in 2014. Unfortunately, there is no data available for September 2014, since the month was very rainy and the cloud coverage of satellite images did not allow us to elaborate any data. Initial $K_{c}$ in the 2013 growing season was high and constant around 0.90, with a maximum value 
of 1.02 close to the harvest, in September. Overall, the standard deviation values of the 2014 data are lower than for the 2013 data, denoting good stability and fairly tight dispersion in the dataset.

Table 3. Statistical parameters for $\mathrm{K}_{\mathrm{c}}$ values derived from Landsat 8 satellite images from the year 2013 ( $n=110$ plots).

\begin{tabular}{ccccccccc}
\hline \multirow{2}{*}{$\mathbf{K}_{\mathbf{c}}$} & $\begin{array}{c}\text { 19 May } \\
\mathbf{2 0 1 3}\end{array}$ & $\begin{array}{c}\mathbf{2 0} \text { June } \\
\mathbf{2 0 1 3}\end{array}$ & $\begin{array}{c}\text { 06 July } \\
\mathbf{2 0 1 3}\end{array}$ & $\begin{array}{c}\mathbf{2 2} \text { July } \\
\mathbf{2 0 1 3}\end{array}$ & $\begin{array}{c}\text { 07 August } \\
\mathbf{2 0 1 3}\end{array}$ & $\begin{array}{c}\mathbf{2 3} \text { August } \\
\mathbf{2 0 1 3}\end{array}$ & $\begin{array}{c}\text { 08 Sept } \\
\mathbf{2 0 1 3}\end{array}$ & $\begin{array}{c}\mathbf{2 4} \text { Sept } \\
\mathbf{2 0 1 3}\end{array}$ \\
\hline maximum & 1.14 & 1.14 & 1.14 & 1.19 & 1.19 & 1.18 & 1.23 & 1.19 \\
average & 0.91 & 0.91 & 0.88 & 0.92 & 0.93 & 0.93 & 1.02 & 0.96 \\
$\begin{array}{c}\text { minimum } \\
\text { Standard }\end{array}$ & 0.58 & 0.58 & 0.43 & 0.46 & 0.48 & 0.49 & 0.58 & 0.56 \\
deviation & 0.13 & 0.13 & 0.15 & 0.15 & 0.14 & 0.14 & 0.13 & 0.13 \\
\hline
\end{tabular}

Table 4. Statistical parameters for $\mathrm{K}_{\mathrm{c}}$ values derived from Landsat 8 satellite images from the year 2014 ( $n=110$ plots).

\begin{tabular}{ccccccc}
\hline Kc & 06 May & 07 June & 23 June & 09 July & 10 August & 26 August \\
& $\mathbf{2 0 1 4}$ & $\mathbf{2 0 1 4}$ & $\mathbf{2 0 1 4}$ & $\mathbf{2 0 1 4}$ & $\mathbf{2 0 1 4}$ & $\mathbf{2 0 1 4}$ \\
\hline maximum & 0.63 & 0.75 & 1.07 & 1.42 & 1.10 & 1.30 \\
average & 0.32 & 0.43 & 0.82 & 1.02 & 0.93 & 1.04 \\
minimum & 0.14 & 0.17 & 0.53 & 0.68 & 0.56 & 0.63 \\
Standard & 0.08 & 0.10 & 0.11 & 0.16 & 0.10 & 0.12 \\
deviation & & & & & & \\
\hline
\end{tabular}

The review of vineyard $\mathrm{K}_{\mathrm{c}}$ values for table grapes available in literature is described in Table 5 . Initial $\mathrm{K}_{\mathrm{c}}$ in 2014 growing season is $0.32-0.43$, closer to the value obtained by Netzer et al. [64] in Israel and Lamaddalena and Caliandro [65] in the same region of our study area. Midseason $\mathrm{K}_{\mathrm{c}}$ in our study area in the two growing seasons was around 0.8 and 1.02, in line with those values reported by Rana [36] in Apulia, and Williams and Ayars [12] in California. The peaks of 1.23 in 2013 and 1.42 in 2014 are consistent with those of Netzer et al. [64], Villagra et al. [66], and Williams and Ayars [12]. All these authors estimated a $\mathrm{K}_{\mathrm{c}}$ value equal to or greater than 1.2 for table grapevine varieties: "Thompson seedless" for Villagra et al. [66] and Williams and Ayars [12], and "Superior Seedless" for Netzer et al. [64].

Figure 7 shows the temporal evolution of $\mathrm{K}_{\mathrm{c}}$ of "tendone" vineyards in 2013 and 2014 together with the $\mathrm{K}_{\mathrm{c}}$ of grapes derived from the FAO-56 paper. Furthermore, arrows marked on the graph indicate the corresponding dates of phenological stages. Regarding the 2013 growing season, it is interesting to note that the "usual" trend of $\mathrm{K}_{\mathrm{c}}$ is not present, probably due to the higher vegetative growth and canopy cover stimulated by high temperatures from bud break up to flowering (Table 2) and regular precipitation. As mentioned in the FAO-56 paper [16], accurate estimates for initial $\mathrm{K}_{\mathrm{c}}$ should consider the frequency with which the soil surface is wetted during the initial period. Where the soil is frequently wet from irrigation or rain, and consequently there is a greater amount of available water, the evaporation from the soil surface can be considerable and the initial $\mathrm{K}_{\mathrm{c}}$ value will be large. 


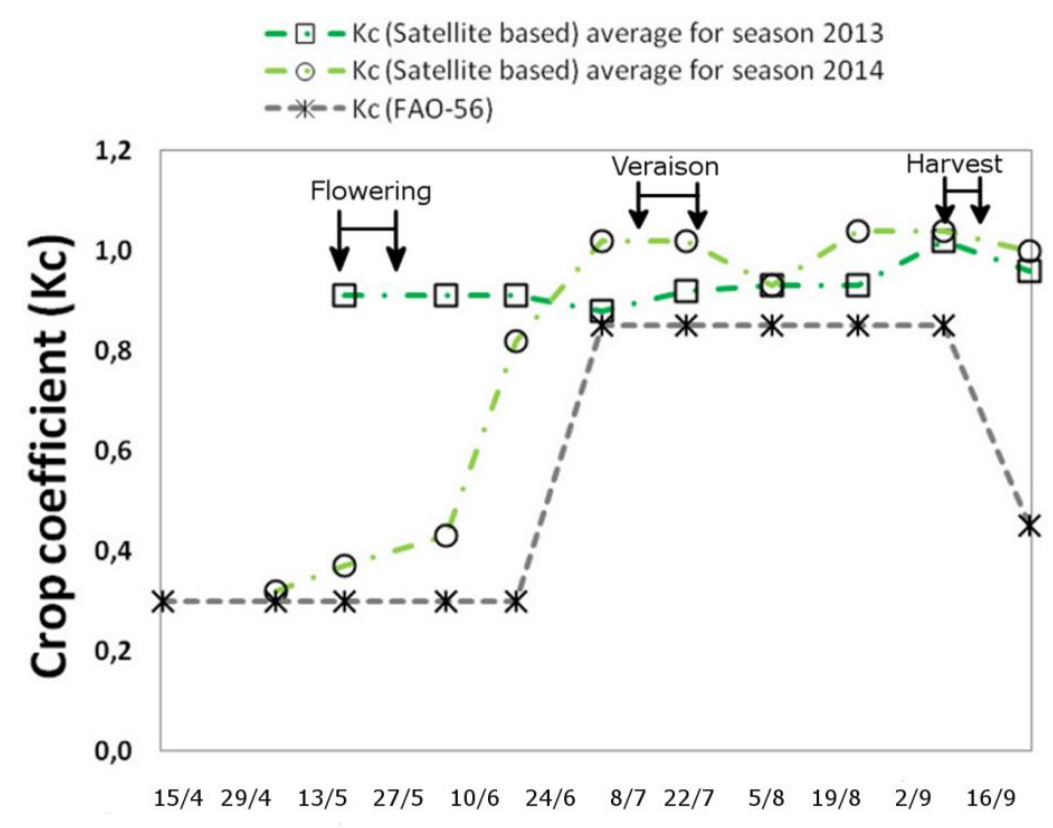

\section{Time}

Figure 7. Comparison of Kc (average) estimated from remote sensing data (Landsat 8) and $\mathrm{K}_{\mathrm{c}}$ from the FAO-56 table.

On the contrary, in the 2014 growing season the trend of estimated $\mathrm{K}_{\mathrm{c}}$ value is similar to the $\mathrm{K}_{\mathrm{c}} \mathrm{FAO}$ trend, with a lower value at the beginning of the season, probably due to low temperatures up to flowering (Table 2), a peak from the first 10 days of July, a slight decrease in the first 10 days of August, and a plateau in the middle of the season. This observation may support the hypothesis that the vegetation growth and $\mathrm{K}_{\mathrm{c}}$ trend, after a slow development, was stimulated by GDD accumulation that at veraison surmount the values of the 2013 growing season.

It is interesting to note that the FAO-56 $\mathrm{K}_{\mathrm{c}}$ value underestimates the local water need of "tendone" vineyards at all phenological stages. These results are consistent with those of Villagra et al. [66], who reported a $\mathrm{K}_{\mathrm{c}}$ value higher than suggested by the FAO-56 paper for Thompson Seedless table grapes in Chile, in growing season 2008-2009 by using the Eddy covariance method. On the contrary, Er-Raki et al. [28] reported $\mathrm{K}_{\mathrm{c}}$ values lower than those presented in the FAO-56 paper for Perlette and Superior table grapes in Northwest Mexico (especially for the mid-season) by using ground-based, remotely-sensed data.

However, in the latter case the authors explained their results by the fact that a " $Y$ " open-gable trellis system creates large areas of unshaded bare soil where significant heat fluxes were lost and were not available for transpiration. A possible explanation for these results may be the lack of adequate consideration of vegetation cover, since $\mathrm{FAO}-56 \mathrm{~K}_{\mathrm{c}}$ values were computed for table grapes trained on a trellis system. Furthermore, this critique was confirmed by Williams and Ayars [12], who suggested that $\mathrm{K}_{\mathrm{c}}$ and water use are linear functions of the shaded area measured beneath the canopy.

A significant analysis and discussion of this subject was presented by Allen and Pereira [67], who proposed a general procedure for estimating $\mathrm{K}_{\mathrm{c}}$ where ground cover and height vary between orchards. In this study the $\mathrm{K}_{\mathrm{c}}$ values for the initial, mid-season, and end-season periods were set to $0.30,1.10$, and 0.85 for a ground cover of $70 \%, 0.30,0.95$, and 0.75 for a ground cover of $50 \%$, and $0.30,0.60$, and 0.5 for a ground cover of $25 \%$. 
Overall, these findings suggest that $\mathrm{K}_{\mathrm{c}}$ in different crop management systems (e.g., trellising and canopy structure) and agro-climatic locations can vary widely and should be accurately estimated for better irrigation scheduling instead of using the fixed values reported in the literature [12].

Table 5. $\mathrm{K}_{\mathrm{c}}$ values of table grapes reported in bibliography.

\begin{tabular}{|c|c|c|c|c|c|c|c|}
\hline \multicolumn{3}{|c|}{$\mathbf{K}_{\mathbf{c}}$} & \multirow{2}{*}{ Trellis System } & \multirow{2}{*}{ Cultivar } & \multirow{2}{*}{ Season } & \multirow{2}{*}{ Country } & \multirow{2}{*}{ References } \\
\hline Initial & Middle & End & & & & & \\
\hline- & $\sim 1$ & - & Tendone & Italia & 1997 & Italy & Rana et al. [36] \\
\hline 0.2 & $0.9-1.3$ & - & Head training system & Thompson seedless & 1998-1999 & California & Williams and Ayars [12] \\
\hline 0.48 & 0.68 & 0.68 & Tendone & - & - & Italy & Lamaddalena and Caliandro [65] \\
\hline 0.4 & $1-1.2$ & 1.3 & Open-gable & Superior seedless & 2004-2005 & Israel & Netzer et al. [64] \\
\hline 0.22 & 0.45 & 0.3 & Open-gable & $\begin{array}{c}\text { Perlette \& Superior } \\
\text { seedless }\end{array}$ & $2005-2006$ & Mexico & Er-Raki et al. [28] \\
\hline- & 0.79 & 0.98 & Open-gable* & Red Globe & $2007-2008$ & Spain & Moratiel and Martinez-Cob [68] \\
\hline 0.54 & 0.65 & 0.9 & Overhead trellis system* & Crimson seedless & 2008-2009 & Spain & \\
\hline 0.47 & 0.60 & - & Overhead trellis system ${ }^{*}$ & Autumn Royal & 2009 & Spain & Suvocarev et al. [22] \\
\hline $0.2-0.4$ & $\sim 0.9-1.2$ & 1.2 & Overhead trellis system & Thompson seedless & $2008-2010$ & Chile & Villagra et al. [66] \\
\hline
\end{tabular}

Note: * Vineyard covered with a net made of a thread warp of high-density polyethylene.

\subsection{Temporal Evolution of Evapotranspiration}

Figure 8 provides an overview of the cumulated $\mathrm{ET}_{\mathrm{p}}$ and 10-day sums trend line during the period between 1 June and 30 September for both growing seasons. In addition, arrows marked on the graph indicate the dates of the main phenological stages. The average $\mathrm{ET}_{\mathrm{p}}$ value ranged from $294 \mathrm{~mm}$ in 2013 to $299 \mathrm{~mm}$ in 2014. These results can be compared with those obtained by Texeira et al. [2], who reported a mean value $\mathrm{ET}_{\mathrm{p}}$ of $372 \mathrm{~mm}$, although, as highlighted by Netzer et al. [64], the comparison between seasonal $\mathrm{ET}_{\mathrm{p}}$ in different regions and different practices can be misleading and might lead to misinterpretations of the results and incorrect inferences.

Figure 8 is quite revealing and interesting in several ways, showing differences especially at midseason. Firstly, the cumulative values for the year 2013 are generally higher than those in year 2014 until the first 10 days of August, while the values have similar trends up to the end of September. As stated previously when referring to the $\mathrm{K}_{\mathrm{c}}$ trend lines, these differences can be explained by several factors. First, we need to consider that the 2013 growing season was initially warmer, with enhanced canopy cover and evaporative demand, and consequently improved daily transpiration. Secondly, the 10-day sums of $\mathrm{ET}_{\mathrm{p}}$ for both seasons show a trend in line with high atmospheric demand during the summer, but with some peaks and decreasing values linked to rainfall events. For example, for both growing seasons we register the peaks of 10-day sums of $\mathrm{ET}_{\mathrm{p}}$ at the days of veraison, but shifted by about 10 days. Furthermore, the peak on the last 20 days of August 2014 might have been influenced by a drought month, while decreasing ET $_{\mathrm{p}}$ values experienced in August 2013 could be attributed to some rain events (about $52 \mathrm{~mm}$ in the last 12 days of the month), more abundant and larger than in 2014 (see Figures 4 and 5), that resulted in cloudy and cool conditions. Although mean monthly air temperature was similar for both months $\left(24.4{ }^{\circ} \mathrm{C}\right.$ for 2013 and $24.6{ }^{\circ} \mathrm{C}$ for 2014$)$, this area is very windy and evapotranspiration trends may also be affected by the wind. Finally, the equal values of $\mathrm{ET}_{\mathrm{p}}$ registered toward the end of the season and in correspondence with the harvest can be attributed to reduced evapotranspiration 
demand and leaf senescence [69]. On the other hand, with regard to the soil water status, it is important to bear in mind that table grape vineyards are constantly irrigated by grape growers to maintain adequate soil water availability to the root-zone.

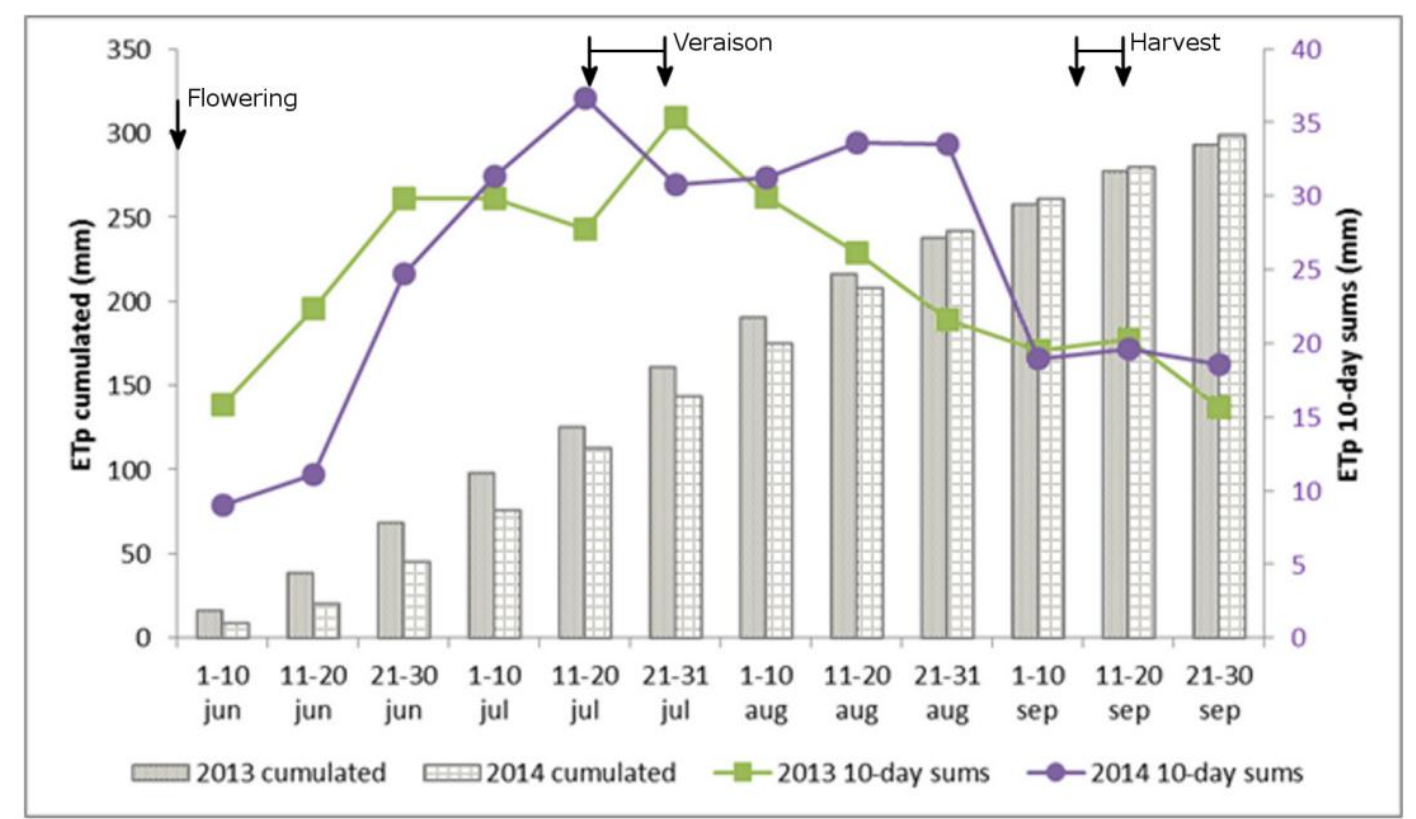

Figure 8. Cumulative values and trend line evolution of ETp.

Furthermore, crop water requirements calculated during the period June-September as the difference between $\mathrm{ET}_{\mathrm{p}}$ and water resulting from precipitation (114.4 mm for 2013 and $164.8 \mathrm{~mm}$ for 2014) show an average irrigation requirement of $179.5 \mathrm{~mm}$ for 2013 and $134.3 \mathrm{~mm}$ for 2014, respectively. The amount of water commonly applied by using drip irrigation in this study area, collected through semi-structured questionnaires engaging grape growers in the 2013season, was approximately $250 \mathrm{~mm}$, close to our $\mathrm{ET}_{\mathrm{p}}$ values. Our results indicate that farmers tend to over-irrigate the crop, due to the unavailability of supporting information about climate and canopy development. Interestingly, a recent study in the same study area shows the possibility of reducing crop water requirements by applying seasonal water volumes, equal to $80 \%$ of $\mathrm{ET}_{\mathrm{p}}$ at the end of irrigation season (about 220-230 mm, in line with our values), with the best balance among grape yield, berry quality, and water use [9]. In addition, visual estimations of time-series in summer 2014 for the LAI, NDVI, $\mathrm{K}_{\mathrm{c}}$, and $\mathrm{ET}_{\mathrm{p}}$ are shown in Figure 9. This figure indicates that the $\mathrm{ET}_{\mathrm{p}}$ and $\mathrm{K}_{\mathrm{c}}$ trend patterns are strictly related with VI at the time of the satellite overpass, but from one date to another are strongly influenced by specific weather conditions and soil moisture. These data show the importance of local climate conditions for water management and irrigation scheduling of the table grapes, and confirm the requirement of site-specific $\mathrm{K}_{\mathrm{c}}$, considering the remarkable seasonality in precipitation during the growing seasons in the study area. Further studies need to be carried out in order to better validate the relation among LAI, $\mathrm{K}_{\mathrm{c}}$, and soil water status. 

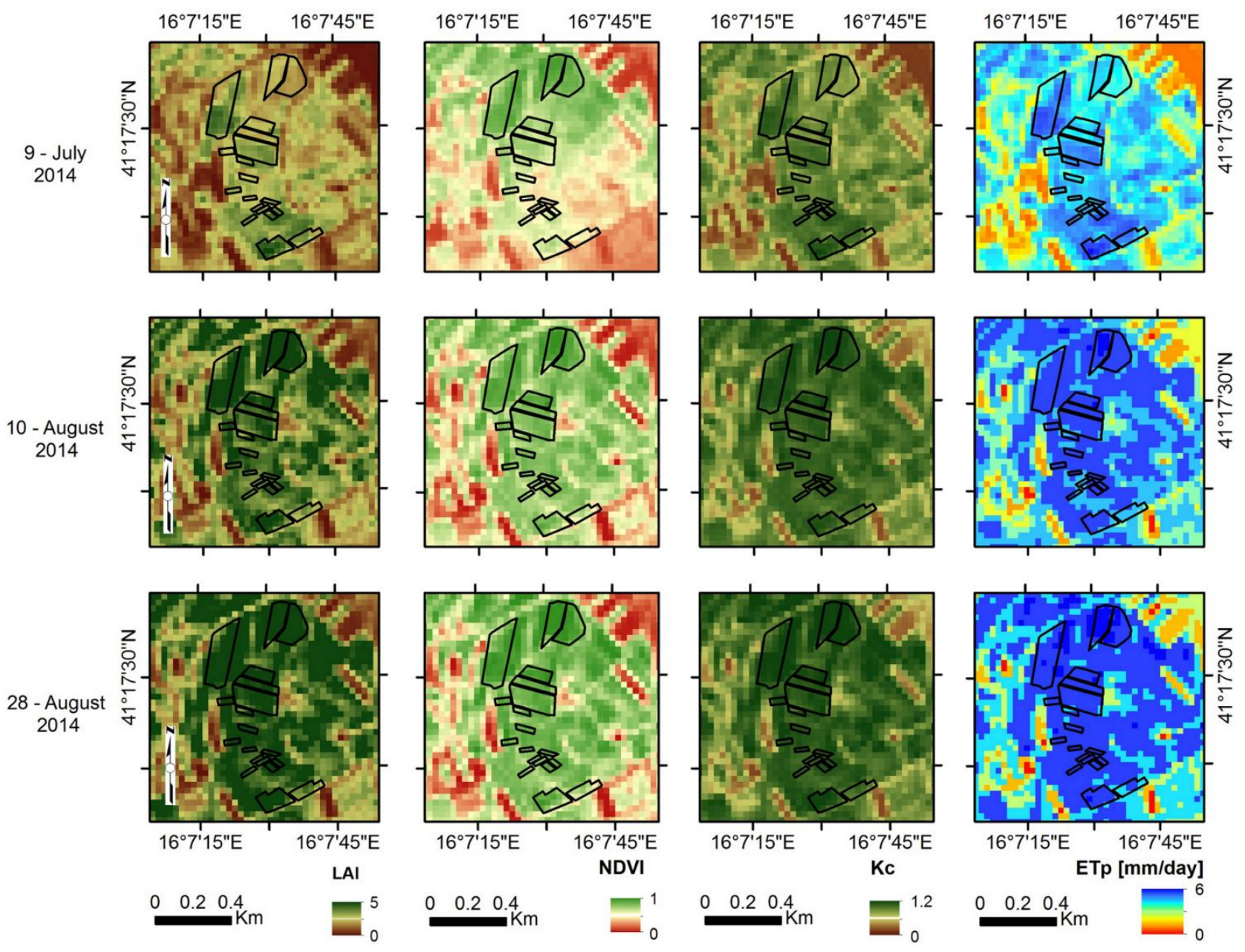

Figure 9. An example of time-series maps of LAI, NDVI, $\mathrm{K}_{\mathrm{c}}$, and $\mathrm{ET}_{\mathrm{p}}$ for the vineyard study field represented in Figure 2.

\section{Conclusions}

This study evaluates the crop coefficients and evapotranspiration of table grapes trained on a "tendone" system under conditions of unlimited soil water availability, pest and disease-free crop, etc. The method is based on the FAO-56 model by using appropriate values of canopy variables such as the surface albedo and the LAI derived by means of multispectral satellite data, based on existing validated methodologies. The results for the study area in the Apulia region (Italy) indicate that the values of $\mathrm{K}_{\mathrm{c}}$ are site- and year-specific and depend on local $\mathrm{ET}_{0}$ rates, rainfall frequency, cumulative thermal requirements, and effective canopy cover. For instance, during the 2013 growing season the Kc value moves from a minimum of 0.43 to a maximum of 1.23 at harvest, while in 2014 the Kc moves from a minimum of 0.14 to a maximum of 1.42 . The obtained results showed good consistency compared with values retrieved from the international literature regarding table grapes in Mediterranean environments, although they should be used with some caution because the calculated ET $_{\mathrm{p}}$ are not the actual values but the maximum values in absence of stress. The resulting crop water requirements are lower than the actual average irrigation volumes applied by farmers, thus suggesting the possibility of improving the water use efficiency of these crops by adopting the proposed methodology. The methodology and results of this research confirm the usefulness of E.O. data in supporting irrigation scheduling and agricultural 
water management. Furthermore, the approach described in this paper also constitutes the basis for a potential irrigation advisory service using E.O. data as an operational service.

\section{Acknowledgments}

This work has been carried out in the framework of IRMA project (www.irrigation-management.eu), subsidy contract no: I3.11.06. It has been co-financed by EU/ERDF (75\%) and national funds of Greece and Italy (25\%) in the framework of the European Territorial Cooperation Programme (ETCP) GREECE-ITALY 2007-2013 (www.greece-italy.eu). A special thanks to Enrico Anzano for the valuable work of field data collection with LAI-Licor 2000 and to Luigi Tarricone for the data on phenological stages.

\section{Author Contributions}

All authors contributed to the research, provided assistance in writing and editing, read and approved the final manuscript.

\section{List of Symbols and Acronyms}

\begin{tabular}{|c|c|}
\hline CLAIR & Clevers' Leaf Area Index by Reflectance model \\
\hline $\mathrm{ET}_{0}$ & Reference evapotranspiration $\left[\mathrm{mm} \cdot \mathrm{d}^{-1}\right]$ \\
\hline $\mathrm{ET}_{\mathrm{p}}$ & Crop evapotranspiration $\left[\mathrm{mm} \cdot \mathrm{d}^{-1}\right]$ \\
\hline fcover & Fractional cover $[\%]$ \\
\hline GDD & Growing Degree Days $\left[{ }^{\circ} \mathrm{C}\right]$ \\
\hline GPS & Global Position System \\
\hline GSD & Ground Sample Distance [m] \\
\hline $\mathrm{h}_{\mathrm{c}}$ & Crop height $[\mathrm{m}]$ (0.12 for reference crop) \\
\hline$h_{c^{*}}$ & Crop height $[\mathrm{m}]$ (constant value of $0.4 \mathrm{~m}$ in this study) \\
\hline $\mathrm{K}_{\mathrm{c}}$ & Crop coefficient [dimensionless] \\
\hline$K^{\downarrow}$ & Global incoming short-wave radiation flux density $\left[\mathrm{W} \cdot \mathrm{m}^{-2}\right]$ \\
\hline LAI & Leaf area index $\left[\mathrm{m}^{2} \cdot \mathrm{m}^{-2}\right](2.88$ for reference crop $)$ \\
\hline LAI* & Leaf area index $\left[\mathrm{m}^{2} \cdot \mathrm{m}^{-2}\right]$ (estimated from satellite) \\
\hline MODTRAN & MODerate resolution atmospheric TRANsmission \\
\hline NDVI & Normalized difference vegetation index [dimensionless] \\
\hline OLI & Operational Land Imager \\
\hline WDVI & Weighted Difference Vegetation Index [dimensionless] \\
\hline$P$ & Actual precipitation $\left[\mathrm{cm} \cdot \mathrm{d}^{-1}\right]$ \\
\hline$P_{n}$ & Net precipitation $\left[\mathrm{cm} \cdot \mathrm{d}^{-1}\right]$ \\
\hline$r$ & Albedo [dimensionless] (0.23 for reference crop) \\
\hline$r^{*}$ & Albedo [dimensionless] (estimated from satellite) \\
\hline
\end{tabular}


List. Cont.

\begin{tabular}{ll}
\hline $\mathrm{R}^{2}$ & Coefficient of determination \\
$\mathrm{RH}$ & Air humidity [\%] \\
$R M S E$ & Root-mean-square error [dimensionless] \\
$\mathrm{r}_{\mathrm{SNIR}}$ & Spectral reflectance in the near-nfrared channel \\
$\mathrm{r}_{\mathrm{SRED}}$ & Spectral reflectance in the red channel \\
$\mathrm{S}$ & Solar radiation \\
$\mathrm{SAVI}$ & Soil Adjusted Vegetation Index [dimensionless] \\
$\mathrm{SEL}$ & Standard error of the LAI \\
$\mathrm{SIMODIS}$ & SImulation and Management of On-Demand Irrigation System \\
$\mathrm{T}_{\mathrm{a}}$ & Air temperature $\left[{ }^{\circ} \mathrm{C}\right.$ ] \\
$\mathrm{U}$ & Wind speed [m· $\mathrm{s}^{-1}$ ] \\
$\mathrm{VI}$ & Vegetation Index [dimensionless] \\
$a$ & Crop saturation per unit foliage area $\left[\mathrm{cm} \cdot \mathrm{d}^{-1}\right.$ ] \\
$\alpha^{*}$ & Extinction coefficient [dimensionless] \\
\hline
\end{tabular}

\section{Conflicts of Interest}

The authors declare no conflict of interest.

\section{References}

1. International Organisation of Vine and Wine. Statistical Report on World Viticulture; International Organisation of Vine and Wine: Paris, France, 2013.

2. De C. Teixeira, A.H.; Bastiaanssen, W.G.M.; Bassoi, L.H. Crop water parameters of irrigated wine and table grapes to support water productivity analysis in the São Francisco river basin, Brazil. Agric. Water Manag. 2007, 94, 31-42.

3. Perry, C.; Steduto, P.; Allen, R.G.; Burt, C.M. Increasing productivity in irrigated agriculture: Agronomic constraints and hydrological realities. Agric. Water Manag. 2009, 96, 1517-1524.

4. Carrasco-Benavides, M.; Ortega-Farías, S.; Lagos, L.O.; Kleissl, J.; Morales, L.; Poblete-Echeverría, C.; Allen, R.G. Crop coefficients and actual evapotranspiration of a drip-irrigated Merlot vineyard using multispectral satellite images. Irrig. Sci. 2012, 30, 485-497.

5. Chaves, M.M.; Zarrouk, O.; Francisco, R.; Costa, J.M.; Santos, T.; Regalado, A.P.; Rodrigues, M.L.; Lopes, C.M. Grapevine under deficit irrigation: Hints from physiological and molecular data. Ann. Bot. 2010, 105, 661-676.

6. Williams, L.E.; Grimes, D.W.; Phene, C.J. The effects of applied water at various fractions of measured evapotranspiration on water relations and vegetative growth of Thompson Seedless grapevines. Irrig. Sci. 2010, 28, 221-232.

7. Aragués, R.; Medina, E.T.; Clavería, I.; Martínez-Cob, A.; Faci, J. Regulated deficit irrigation, soil salinization and soil sodification in a table grape vineyard drip-irrigated with moderately saline waters. Agric. Water Manag. 2014, 134, 84-93. 
8. Faci, J.M.; Blanco, O.; Medina, E.T.; Martínez-Cob, A. Effect of post veraison regulated deficit irrigation in production and berry quality of Autumn Royal and Crimson table grape cultivars. Agric. Water Manag. 2014, 134, 73-83.

9. Tarricone, L.; Gentilesco, G.; Di Gennaro, D.; Amendolagine, A.M. Irrigation strategy and vine performance of organic "Italia" table grape grown in Apulia region (Southern Italy). In Proceedings of the 7th International Table Grape Symposium, Mildura, Victoria, Australia, 11-14 November 2014; pp. 97-100.

10. García García, J.; Martínez-Cutillas, A.; Romero, P. Financial analysis of wine grape production using regulated deficit irrigation and partial-root zone drying strategies. Irrig. Sci. 2012, 30, 179-188.

11. Medrano, H.; Tomás, M.; Martorell, S.; Escalona, J.-M.; Pou, A.; Fuentes, S.; Flexas, J.; Bota, J. Improving water use efficiency of vineyards in semi-arid regions. A review. Agron. Sustain. Dev. 2014, 35, 499-517.

12. Williams, L.E.; Ayars, J.E. Grapevine water use and the crop coefficient are linear functions of the shaded area measured beneath the canopy. Agric. For. Meteorol. 2005, 132, 201-211.

13. López-Urrea, R.; Montoro, A.; Mañas, F.; López-Fuster, P.; Fereres, E. Evapotranspiration and crop coefficients from lysimeter measurements of mature "Tempranillo" wine grapes. Agric. Water Manag. 2012, 112, 13-20.

14. Li, S.; Tong, L.; Li, F.; Zhang, L.; Zhang, B.; Kang, S. Variability in energy partitioning and resistance parameters for a vineyard in northwest China. Agric. Water Manag. 2009, 96, 955-962.

15. Li, S.; Kang, S.; Li, F.; Zhang, L.; Zhang, B. Vineyard evaporative fraction based on eddy covariance in an arid desert region of Northwest China. Agric. Water Manag. 2008, 95, 937-948.

16. Ortega-Farias, S.; Carrasco, M.; Olioso, A.; Acevedo, C.; Poblete, C. Latent heat flux over Cabernet Sauvignon vineyard using the Shuttleworth and Wallace model. Irrig. Sci. 2007, 25, 161-170.

17. Pellegrino, A.; Gozé, E.; Lebon, E.; Wery, J. A model-based diagnosis tool to evaluate the water stress experienced by grapevine in field sites. Eur. J. Agron. 2006, 25, 49-59.

18. Zhang, Y.; Kang, S.; Ward, E.J.; Ding, R.; Zhang, X.; Zheng, R. Evapotranspiration components determined by sap flow and microlysimetry techniques of a vineyard in northwest China: Dynamics and influential factors. Agric. Water Manag. 2011, 98, 1207-1214.

19. Carrasco-Benavides, M.; Ortega-Farías, S.; Lagos, L.; Kleissl, J.; Morales-Salinas, L.; Kilic, A. Parameterization of the Satellite-Based Model (METRIC) for the Estimation of Instantaneous Surface Energy Balance Components over a Drip-Irrigated Vineyard. Remote Sens. 2014, 6, 11342-11371.

20. Allen, R.G.; Pereira, L.S.; Raes, D.; Smith, M. Crop Evapotranspiration-Guidelines for Computing Crop Water Requirements-FAO Irrigation and Drainage Paper 56; Food and Agriculture Organization of the United Nations: Rome, Italy,1998.

21. Pereira, L.S.; Allen, R.G.; Smith, M.; Raes, D. Crop evapotranspiration estimation with FAO56: Past and future. Agric. Water Manag. 2014, 147, 4-20.

22. Suvočarev, K.; Blanco, O.; Faci, J.M.; Medina, E.T.; Martínez-Cob, A. Transpiration of table grape (Vitis vinifera L.) trained on an overhead trellis system under netting. Irrig. Sci. 2013, 31, 1289-1302.

23. Kamble, B.; Kilic, A.; Hubbard, K. Estimating crop coefficients using remote sensing-based vegetation index. Remote Sens. 2013, 5, 1588-1602. 
24. Moriondo, M.; Jones, G.V.; Bois, B.; Dibari, C.; Ferrise, R.; Trombi, G.; Bindi, M. Projected shifts of wine regions in response to climate change. Clim. Chang. 2013, 119, 825-839.

25. Moriondo, M.; Ferrise, R.; Trombi, G.; Brilli, L.; Dibari, C.; Bindi, M. Modelling olive trees and grapevines in a changing climate. Environ. Model. Softw. 2015, 72, 387-401.

26. Campos, I.; Neale, C.M.U.; Calera, A.; Balbontín, C.; González-Piqueras, J. Assessing satellite-based basal crop coefficients for irrigated grapes (Vitis vinifera L.). Agric. Water Manag. 2010, 98, 45-54.

27. Galleguillos, M.; Jacob, F.; Prévot, L.; French, A.; Lagacherie, P. Comparison of two temperature differencing methods to estimate daily evapotranspiration over a Mediterranean vineyard watershed from ASTER data. Remote Sens. Environ. 2011, 115, 1326-1340.

28. Er-Raki, S.; Rodriguez, J.C.; Garatuza-Payan, J.; Watts, C.J.; Chehbouni, A. Determination of crop evapotranspiration of table grapes in a semi-arid region of Northwest Mexico using multi-spectral vegetation index. Agric. Water Manag. 2013, 122, 12-19.

29. D’Urso, G.; Richter, K.; Calera, A.; Osann, M.A.; Escadafal, R.; Garatuza-Pajan, J.; Hanich, L.; Perdigão, A.; Tapia, J.B.; Vuolo, F. Earth Observation products for operational irrigation management in the context of the PLEIADeS project. Agric. Water Manag. 2010, 98, 271-282.

30. Glenn, E.P.; Huete, A.R.; Nagler, P.L.; Nelson, S.G. Relationship between remotely-sensed vegetation indices, canopy attributes and plant physiological processes: What vegetation indices can and cannot tell us about the landscape. Sensors 2008, 8, 2136-2160.

31. Allen, R.G.; Pereira, L.S.; Howell, T.A.; Jensen, M.E. Evapotranspiration information reporting: I. Factors governing measurement accuracy. Agric. Water Manag. 2011, 98, 899-920.

32. Er-Raki, S.; Chehbouni, A.; Guemouria, N.; Duchemin, B.; Ezzahar, J.; Hadria, R. Combining FAO56 model and ground-based remote sensing to estimate water consumptions of wheat crops in a semi-arid region. Agric. Water Manag. 2007, 87, 41-54.

33. Er-Raki, S.; Chehbouni, A.; Duchemin, B. Combining satellite remote sensing data with the FAO-56 dual approach for water use mapping in irrigated wheat fields of a semi-arid region. Remote Sens. 2010, 2, 375-387.

34. Duchemin, B.; Hadria, R.; Erraki, S.; Boulet, G.; Maisongrande, P.; Chehbouni, A.; Escadafal, R.; Ezzahar, J.; Hoedjes, J.C.B.; Kharrou, M.H.; et al. Monitoring wheat phenology and irrigation in Central Morocco: On the use of relationships between evapotranspiration, crops coefficients, leaf area index and remotely-sensed vegetation indices. Agric. Water Manag. 2006, 79, 1-27.

35. Consoli, S.; Barbagallo, S. Estimating Water Requirements of an Irrigated Mediterranean Vineyard Using a Satellite-Based Approach. J. Irrig. Drain. Eng. 2012, 138, 896-904.

36. Rana, G.; Katerji, N.; Introna, M.; Hammami, A. Microclimate and plant water relationship of the "overhead" table grape vineyard managed with three different covering techniques. Sci. Hortic. (Amsterdam) 2004, 102, 105-120.

37. Justice, C.; Townshend, J. Special issue on the moderate resolution imaging spectroradiometer (MODIS): A new generation of land surface monitoring. Remote Sens. Environ. 2002, 83, 1-2.

38. Fandiño, M.; Cancela, J.J.; Rey, B.J.; Martínez, E.M.; Rosa, R.G.; Pereira, L.S. Using the dual-Kc approach to model evapotranspiration of Albariño vineyards (Vitis vinifera L. cv. Albariño) with consideration of active ground cover. Agric. Water Manag. 2012, 112, 75-87. 
39. Vuolo, F.; D’Urso, G.; De Michele, C.; Bianchi, B.; Cutting, M. Satellite-based Irrigation Advisory Services: A common tool for different experiences from Europe to Australia. Agric. Water Manag. 2015, 147, 82-95.

40. ISTAT 6 Censimento Generale dell'Agricoltura. Available online: http://dati-censimentoagricoltura. istat.it/ (accessed on 3 July 2015).

41. Vanino, S.; Nino, P.; De Michele, C.; Bolognesi, S.F.; Pulighe, G. Earth Observation for Improving Irrigation Water Management: A Case-study from Apulia Region in Italy. Agric. Agric. Sci. Procedia 2015, 4, 99-107.

42. Benedetti, A.; Teresa, M.; Abate, D.; Napoli, R. The Soils of Italy; Edoardo, A.C., Costantini, C.D., Eds.; Springer: Dordrecht, Netherlands, 2013.

43. Winkler, A.J.; Cook, J.A.; Kliewer, W.M.; Lider, L.A. General Viticulture, 2nd ed.; University of California Press: Oakland, CA, USA, 1974.

44. LI-COR. LAI-2000 Plant Canopy Analyzer Instruction Manual 1992. Available online: http:// www.licor.com/env/products/leaf_area/LAI-2200/ (accessed on 3 July 2015).

45. D’Urso, G. Simulation and Management of on-Demand Irrigation Systems: A Combined Agrohydrological and Remote Sensing Approach. PhD Thesis, Wageningen Agricultural University, Wageningen, Netherlands, 2001.

46. Minacapilli, M.; Iovino, M.; D’Urso, G. A distributed agro-hydrological model for irrigation water demand assessment. Agric. Water Manag. 2008, 95, 123-132.

47. Minacapilli, M.; Agnese, C.; Blanda, F.; Cammalleri, C.; Ciraolo, G.; D’Urso, G.; Iovino, M.; Pumo, D.; Provenzano, G.; Rallo, G. Estimation of actual evapotranspiration of Mediterranean perennial crops by means of remote-sensing based surface energy balance models. Hydrol. Earth Syst. Sci. 2009, 13, 1061-1074.

48. Braden, H. Ein Energiehaushalts- und Verdunstungsmodell for Wasser und Stoffhaushaltsuntersuchungen landwirtschaftlich genutzer Einzugsgebiete. M. Dtsch. Bodenkd. Geselschaft 1985, 42, 294-299.

49. FAO. Irrigation Scheduling: From Theory to Practice. In Water Reports 8, Proceedings of the ICID/FAO Workshop on Irrigation Scheduling, Rome, Italy, 12-13 September 1995; Food and Agriculture Organization of the United Nations: Rome, Italy, 1996.

50. Akdim, N.; Alfieri, S.; Habib, A.; Choukri, A.; Cheruiyot, E.; Labbassi, K.; Menenti, M. Monitoring of Irrigation Schemes by Remote Sensing: Phenology versus Retrieval of Biophysical Variables. Remote Sens. 2014, 6, 5815-5851.

51. De Vries, C.; Danaher, T.; Denham, R.; Scarth, P.; Phinn, S. An operational radiometric calibration procedure for the Landsat sensors based on pseudo-invariant target sites. Remote Sens. Environ. 2007, 107, 414-429.

52. Vicente-Serrano, S.; Pérez-Cabello, F.; Lasanta, T. Assessment of radiometric correction techniques in analyzing vegetation variability and change using time series of Landsat images. Remote Sens. Environ. 2008, 112, 3916-3934.

53. Richter, R. Atmospheric Correction Methodology for Imaging Spectrometer Data. In The Digital Airborne Spectrometer Experiment (DAISEX); Wooding, M., Harris, R.A., Eds.; European Space Agency: Noordwijk, The Netherlands 2001.

54. Bréda, N.J.J. Ground-based measurements of leaf area index: A review of methods, instruments and current controversies. J. Exp. Bot. 2003, 54, 2403-2417. 
55. Clevers, J.G.P.W. The application of a weighted infrared-red vegetation index for estimating leaf area index by correcting for soil moisture. Remote Sens. Environ. 1989, 29, 25-37.

56. Vuolo, F.; Neugebauer, N.; Bolognesi, S.F.; Atzberger, C.; D’Urso, G. Estimation of leaf area index using DEIMOS-1 data: Application and transferability of a semi-empirical relationship between two agricultural areas. Remote Sens. 2013, 5, 1274-1291.

57. Clevers, J.G.P.W. The derivation of a simplified reflectance model for the estimation of leaf area index. Remote Sens. Environ. 1988, 25, 53-69.

58. Jones, G.V.; Duff, A.A.; Hall, A.; Myers, J.W. Spatial Analysis of Climate in Winegrape Growing Regions in the Western United States. Am. J. Enol. Vitic. 2010, 61, 313-326.

59. Ramos, M.C.; Martínez-Casasnovas, J.A. Effects of precipitation patterns and temperature trends on soil water available for vineyards in a Mediterranean climate area. Agric. Water Manag. 2010, 97, 1495-1505.

60. Williams, L.E. Interaction of applied water amounts and leaf removal in the fruiting zone on grapevine water relations and productivity of Merlot. Irrig. Sci. 2012, 30, 363-375.

61. Poblete-Echeverría, C.A.; Ortega-Farias, S.O. Evaluation of single and dual crop coefficients over a drip-irrigated Merlot vineyard (Vitis vinifera L.) using combined measurements of sap flow sensors and an eddy covariance system. Aust. J. Grape Wine Res. 2013, 19, 249-260.

62. Tomasi, D.; Jones, G.V.; Giust, M.; Lovat, L.; Gaiotti, F. Grapevine Phenology and Climate Change: Relationships and Trends in the Veneto Region of Italy for 1964-2009. Am. J. Enol. Vitic. 2011, 62, 329-339.

63. Baronti, S.; Vaccari, F.P.; Miglietta, F.; Calzolari, C.; Lugato, E.; Orlandini, S. Impact of biochar application on plant water relations in Vitis vinifera(L.). Eur. J. Agron. 2014, 53, 38-44.

64. Netzer, Y.; Yao, C.; Shenker, M.; Bravdo, B.A.; Schwartz, A. Water use and the development of seasonal crop coefficients for Superior Seedless grapevines trained to an open-gable trellis system. Irrig. Sci. 2009, 27, 109-120.

65. Lamaddalena, N.; Caliandro, A. Riorientamenti Produttivi del Territorio Agricolo Pugliese per uno Sviluppo Rurale Sostenibile: Promozione di Servizi Orientati allo Sviluppo Agricolo-Azione 3; Regione Puglia \& CIHEAM Istituto agronomico mediterraneo di Bari: Valenzano, Italy, 2008.

66. Villagra, P.; García de Cortázar, V.; Ferreyra, R.; Aspillaga, C.; Zuñiga, C.; Ortega-Farias, S.; Selles, G. Estimation of water requirements and Kc values of "Thompson Seedless" table grapes grown in the overhead trellis system, using the Eddy covariance metho. Chil. J. Agric. Res. 2014, 74, 213-218.

67. Allen, R.G.; Pereira, L.S. Estimating crop coefficients from fraction of ground cover and height. Irrig. Sci. 2009, 28, 17-34.

68. Moratiel, R.; Martínez-Cob, A. Evapotranspiration of grapevine trained to a gable trellis system under netting and black plastic mulching. Irrig. Sci. 2012, 30, 167-178.

69. De Azevedo, P.V.; Soares, J.M.; Da Silva, V.P.R.; Da Silva, B.B.; Nascimento, T. Evapotranspiration of "Superior" grapevines under intermittent irrigation. Agric. Water Manag. 2008, 95, 301-308.

(C) 2015 by the authors; licensee MDPI, Basel, Switzerland. This article is an open access article distributed under the terms and conditions of the Creative Commons Attribution license (http://creativecommons.org/licenses/by/4.0/). 